${ }^{I}$ Federal University of Rio de Janeiro (UFRJ),

Department of Sociology, Rio de Janeiro, RJ, Brazil

glauciavboas@gmail.com

Glaucia Villas Bôas'

\title{
CHANGE, TIME AND SOCIOLOGY ${ }^{1}$
}

In this article I wish to reflect upon critics and proponents of modernity. My aim is to revisit sociological discourses on the 'modern era' without falling prey to the polarity between good and bad modernity. On one hand, the modern project valued freedom, individuality and citizen rights, foregrounding adult individuals and their capacity to imbue meanings to their lives; it brought hope of a fairer world with less poverty and it brought science, a new modality of knowledge on life and the world. But on the other hand, the freedoms won did not apply equally to everyone: on the contrary, an excessive control of every gesture and action was established, pursued in increasingly sophisticated ways and contributing to the violence in different spheres of life. Social inequalities became indescribable, the concentration of wealth unthinkable and human relations commoditized. Science contributed to wars and conflicts.

I admit that I would have lacked the courage to confront such a complex and wide-ranging theme, already discussed by many others, had it not been present in some form in my own trajectory as a researcher. In cultural production - whether we are dealing with sociological or artistic narratives, my own preferred themes - a specific underlying conception of time is always at work. The interest in learning about the specific relations of change or conservation in relation to conceptions of time has been a constant part of my work. Indeed this explains my choice of topic. Perhaps it would have been easier to praise or critique modernity, but my reflections have not led me to adopt either path. 
The meaning of the word 'modernity' is controversial. One of the most uncontentious ways of defining it as a period is fascinated by the future. Generations of individuals and groups felt attracted to the open and indefinite future, which implied a new perception of time and a new space of experience. An extremely rich collection of philosophical and literary writings, among which we can highlight new textual genres like manifestos, containing proposals, images, expectations and hopes for a better world. Many of these ideas took concrete shape in the world, acquiring an imperfect form both in the spheres of culture, art, literature, music, philosophy and science, but also in actions, clashes, uprisings and revolutions whenever the illusions and utopias impelled men and women to fight for a fairer future.

Under modernity, the future became definitively associated with change, insofar as the term normally signifies the new, the different, an 'other' never before seen. Indeed the future became a kind of guarantee of the hopes of individuals and collectivities.

In recent decades, however, the conducts and expectations concerning the future as a bearer of the new and of progress have been subject to heavy critique. The failure of the utopic worldviews, the rejection of a linear and homogenizing historical narrative, the devastating consequences of technical progress, have given way to a new vision of temporality that, underlying the contingent, the ephemeral and the fleeting, prioritizes memory, safeguarding it in different records of the past. Although the critique of modernity has become ever more vigorous and visible, this seems to have overlooked other spheres of individual, collective, social, economic and political life in which progress, the future and the speeding up of time continue to be unavoidable everyday demands. (It suffices to recall the criteria that define the assessment programs for our activities at university, for instance.) This gap in critique has accentuated the polarity among the narratives on modernity, provoking dissonances, disjunctions and tensions by contributing to an important debate between intellectuals and artists without, though, successfully broadening the scope of its argumentation to the teleologies of everyday actions - the finalities, purposes and projects oriented towards the future, improvement and enhancement of individuals and social institutions.

In the attempt to advance the discussion on the polarity of the narratives on the modern, I shall make three ponderations. The first concerns the modern conception of time, formulated by the German historian and theorist Reinhardt Kosseleck, while the second focuses on various ambivalences and the third examines the temporalities of artistic projects. With these ponderations sketched here in a still inexact and non-systematic form, I intend to show how the discourses against and in favour of the modern, apparently limited to the sphere of culture itself, neglected other social orders constitutive of modern society. This oversight creates a distortion between critical semantics and social structures. 


\section{FIRST PONDERATION: TIME AND ITS ACCELERATION}

The 'modern era,' we are told, freed human beings from the limits of religious explanations of the world. An extraordinary historical feat with repercussions on all spheres of life - political, cultural, economic and erotic - secularization freed people from the shackles of religious beliefs, emancipating individuals and collectivities. The overturning of the dominance of religious explanations of the world exposed contingency, spontaneity, the unexpected and the imponderable, clearing the way for a desire to shape the world according to a prior plan aimed at dominating it. The process of secularization attained another level when the Enlightenment subjected thought and the reformation of the world to science and reason. From the outset, therefore, the shaping of both the world and the individual depended on a singular kind of knowledge, a foundation necessary to any project or prior plan.

In some regions of Western Europe, the experience of a secularized world radically altered the relations between past, present and future. The valorisation of the past specific to the conception of history as a magistra vitae which took past events as exemplary, gave way to the philosophies of history, focused on the singularity of historical processes and their ineluctable progression, despite the fact such processes result from human action. While history as a magistra vitae was founded on the constancy of human nature, making use of histories as an adequate means to prove moral, legal, theological or political doctrines, the new conception of history, by separating history from nature, established a time determined by history itself. This temporalization of history was founded on the notion of progress "in which a certain determination of time becomes manifest, transcendent to nature and immanent to history" (Koselleck, 2006: 55). Under modernity, the task of assimilating the world to human designs (an endeavour Max Weber considered the most difficult) unites the rejection of the past and the adherence to progress. Here we touch on one of the key categories of modern temporality: progress, something that has no end, something that brings the promise of infinite perfection.

Maarten Doorman, a Dutch philosopher, compares progress in art to the Hydra, a many-headed monster fought by Hercules, aware that if he cut off one of the heads, another would be born instantly. Doorman argues that Hercules was more successful than the twentieth-century critics of progress, whose task remains incomplete (Doorman, 2003).

Indeed, the critique of progress was apparently unable to deter it. Its auspicious and tenebrous faces are revealed simultaneously and paradoxically each and every day in the positive advances of technology and in the drama of the forced relocations of populations, city violence, the brutality of wars and the problems related to energy sources. 
Irrespective of which face we wish to contemplate, the speeding up of time constitutes one of the most notable consequences of progress. Historian Reinhardt Koselleck distinguished two problems caused by the acceleration of time: the first relates to the fact that the acceleration of time became a criterion for determining the political hierarchy between different collectivities. The experiences of development, evolution or progress were judged by their speed or their slowness. Koselleck argues that "[a]s part of a group, a country, or finally, a class, one was conscious of being advanced in comparison with the others; or one sought to catch up with or overtake the others. One might be superior technically and look down on previous states of development enjoyed by other peoples, whose guidance was thus a justifiable task for their civilized superiors" (Koselleck, 2006: 3I7). The second problem involves the relation between the horizon of expectation and the space of experience, concepts used by the historian to demonstrate that historical experience is transformed into an experience of transition, an experience of permanent surprise. With past experiences losing their value, the future ceases to be predictable based on what occurred in the past, transforming into something unknown. The concept of progress erased the temporal difference between experience and expectation, terminating the secret connection between the ancient and the future.

It must be recognized, however, that the orientation towards the future in the light of progress and the acceleration of time is not only manifested in the 'great' social transformations or technological revolutions, lest we risk omitting one of the deepest changes that it engendered in social behaviour. Hence the problem. The orientation towards the future was impregnated surreptitiously with little fanfare in quotidian, continuous and prosaic actions, imposing itself on the day-to-day life of school curricula, the calculations of industrial production, the forecasting of commercial profit, the strategies of political parties and unions, and the supply of material and symbolic assets of the State, always aimed at the future improvement of its objectives. This progressive institutionalization of regularly standardized conducts oriented towards future objectives, described by Max Weber (1999: 213) in a chapter from Economy and society, apparently remains outside the critique of the modern conception of time. Such forms of conduct, quotidian and devoid of any glamour, are seen as an event so vulgar and commonplace that the chance of comparing it to the grandiosity of the political, social, scientific and technological revolutions is practically null. However, it is precisely in the tasks and the official or private everyday activities that the demand for speed is felt, further inducing the acceleration of time. The triad of future, progress and velocity was maintained as an ideal to be attained in the daily life of modern institutions, transforming into a rigorous form of recognized and legitimized social control.

It should not be imagined, however, that the focus on progress and future improvement is a prerogative of social institutions. The modern indi- 
vidual is ready to improve herself and develop her qualities in a gradual process in her lifetime. Here it is worth turning to the idea of Bildung which describes the constitution of individual identity as a future-oriented process. Bildung refers to the tradition of self-cultivation, a doubly personal and cultural process aimed at harmonizing the spirt and the heart, and exercising an autonomous subjectivity through the tension between self-determination and socialization. Education thus involves a constant process of becoming that challenges the individual and her beliefs. Although there is no defined telos as such, the idea of Bildung can be seen to possess a teleology insofar as it postulates the continuous expansion and improvement of the individual's spiritual and cultural sensibilities.

\section{SECOND PONDERATION: THE AMBIVALENCES OF SOCIOLOGY}

The role that sociology performed and still performs in research, critique and reflection on modernity is notable. From classic sociology to its contemporary version, despite the range of its premises and theoretical-conceptual frameworks, the discipline has worked to understand the process of change in the world, sometimes distinguishing modalities distinct from a particular 'modelling,' at other times inquiring into their similarities. In studying the transition between traditional and modern social formations, sociology attributed a positive role to individualization, the freedom to come and go, individual merit and authorship - in sum, to the emancipation of the adult individual ready to decide on her own destiny, to the individual as a citizen, a position not necessarily matching the discipline's commitment to the modern forms of sociability typical of western capitalism.

Here it is also worth recalling the dissatisfaction of classic authors like Émile Durkheim and Max Weber in the face of the 'malaise' generated by the order and values of western capitalist society. The concept of anomie created by Durkheim in his books The division of labour in society (1893) and Suicide (I897) leaves no doubt as to his repudiation of the unruliness of modern society, whose economic progress he judged to be the source of all evils, especially given the speed with which it induced social changes. This observation of the absence of norms and moral rules, and thus a lack of the regulation that ensures solidarity between individuals, did not initially seem so threatening to Durkheim. In The division of labour in society he is convinced that history will provide the conditions to establish a new solidarity, founded on the division of labour. However the same does not occur in Suicide. In this work, the exasperated language and very evident disquiet as he returns to the concept of anomie are striking. Now when referring to anomie he questions the authority of society to recover its moral equilibrium. He highlights the excess of individual appetites and passions, expressing his indignation over the infinite 
ambitions that only cause melancholy, unhappiness and a constant source of sadness. However, the most serious dimension for Durkheim is that such passions constitute a mark of moral distinction:

The longing for infinity is daily represented as a mark of moral distinction, whereas it can only appear within unregulated consciences which elevate to a rule the lack of rule from which they suffer. The doctrine of the most ruthless and swift progress has become an article of faith (Durkheim, I982: 203).

Although Durkheim evokes the suffering of young Werther to provide an insight into the individual tragedies caused by the frustration of exacerbated desires, the French Revolution is the target of his political critiques. In the final pages of Suicide, in a section entitled 'Practical considerations,' Durkheim sharpens his critique of modernity, progress, the refusal of the past, and the prediction of the future. In the section 'Practical consequences,' the centre of the maladies shifts from economic progress to the political. According to Durkheim, the French Revolution had carried out a process of levelling in the country never before seen. Many of the entities regulating social life had been annihilated. From the torment - a word he uses in the original - caused by the revolution, only the State had survived. And the latter tried continually to rein in the things that evaded its clutches, or appropriated and violated them. His recommendation to organize the collective force of corporations had no intention of restoring "social forms which are outworn [...] or to create out of whole cloth entirely new forms without historical analogies" (Durkheim, I982: 313). For him, the need was to search the past for the seeds of new life and hasten their development. It is impossible, though, to determine exactly how the seeds of the past will germinate in the future. Durkheim favours science-based diagnoses, but does not believe that science can become a field capable of predicting everything since only things can imbue the teachings of science with the determination that they lack. "Nor must one exaggerate the importance of the too definite programs generally embraced by our political philosophers [...] social reality is not neat enough and is too little understood as yet to be anticipated in detail" (Durkheim, I982: 3I4). In reality, suicide is a symptom of anomie, the author affirms, and his book's objective, first and foremost, is to raise questions "closely connected with the most serious practical problems of the present time" (Durkheim, I982: 313).

Even though Durkheim and Weber adopt quite distinct premises in their investigation of the features of capitalist society, both are broadly concerned with the question of the finitude and infinitude of human desires. In The protestant ethic and the spirit of capitalism (I967), Max Weber condemns the avarice, voracity or acquisitive drive, a term that he uses more frequently, the desire to amass more and more. What seems even stranger to him, however, is that the desire to acquire ever more money turns into a moral duty. How can avarice become a virtue and the acquisition of more and more money an obliga- 
tion? This infinite desire appears both in the ambitions of an old grocer from Ohio, whose daylight hours were dedicated to expanding his shop, and the ambitions of the great entrepreneur Cecil Rhodes, who wanted to annex the stars and the planets to his wealth. Recalling these examples, Weber argues that the values of secular asceticism did not result in the construction of a pious but materialist world, focused on the acquisition of wealth as the greatest meaning of life. Weber expresses surprise that, over the course of history, social agents can engender through their meaningful actions something so different to what they had intended. He laments the unfathomable nature of the future, which he considers a real tragedy in a world oriented towards predicting and controlling the future (Villas Bôas, 2006b). Weber's critiques in the final sections of The protestant ethic and the spirit of capitalism do not impede him, however, from showing over the course of his work that the modern capitalist order was founded on human calculations and predictions, rooted in rationality and necessary to any planning of individual and collective life.

Years after the publication of the two articles that gave rise to The protestant ethic and the spirit of capitalism, published in I904 and I905, in his talk 'Science as a vocation,' given in I9I8, Weber returns to his critique of modernity, focusing on the meaning of modern science, a form of knowledge inseparable from the notion of progress, and whose results are destined to age and be replaced quickly ad infinitum. Here the author focuses on the disenchantment of the world, the absence of a meaning to life and, consequently, the absence of a meaning to death, caused by the infinite nature of scientific knowledge. Science required an end to the illusions of meaning since it was intimately connected to the progress that continually renewed itself. But why then devote oneself to something that, in reality, never comes to an end? Why, Weber asked, does science orient practical life by providing it with technical means? And, moreover, why, as a profession undertaken in a specific area, is science at the service of self-reflection and the knowledge of concrete contexts? Yet it does not offer the meaning of life. Weber cites Tolstoy in three passages related to the absence of the meaning of death under modernity. These excerpts from The death of Ivan Ilyich recall the complete indifference of Ivan's doctors to his pain and suffering. He is treated by his doctors in the same way that Ivan, as a lawyer, treated defendants - merely following the technical precepts of his profession without ever paying any attention to their lives. His life became so devoid of value that, shortly before dying, Ivan Ilyich remarks that his doctor, arriving at his house for a consultation, seems to want to ask him "How's business? - but he realized that he should not talk about such things" (Tolstoy, I993: 918-9I9).

For our discussion it is important to emphasize that the central target of the critiques developed by the two classic authors of sociology is progress and its consequences - the unending novelties, both in material production 
and in immaterial and symbolic production, but above all the quickness and speed with which they appear in the world and provoke insatiable demands in all spheres of social life. Although he affirms that progress always involves anomie, Durkheim offers a possible solution to the regulation of the social sphere through professional corporations. Weber, by contrast, laments that the unlimited drive towards acquisition has become a constitutive value of western capitalism. Nothing remains to be done in terms of the imponderability and the lack of meaning of life provoked by progress apart from responding "to the demands of each day humanely and professionally [...]. But this only happens when each person obeys the devil who pulls the strings of life" (Weber, I995: 45).

We can ask whether Brazilian sociologists from the mid-twentieth century, like Florestan Fernandes, Luiz Aguiar Costa Pinto and Alberto Guerreiro Ramos, followed Weber's guidance and sought to respond to the demands of everyday life. If they did so, then the difference between them would reside in the social and historical nature of the day-to-day world with which they were confronted. If we compare Brazilian sociological thought to classic sociology, even a cursory analysis shows that the reading that Brazilian sociologists made of the French and German sociologists was informed by the urgency of their own pragmatic questions. Their objectives were clear: the institutionalization of sociology and the establishment in the country of a modern industrial, legal and egalitarian capitalist system, founded on science and technology. This perspective was combined with a modern conception of history, processual and progressive, founded on the rejection of the past. Certainly the motto of President Juscelino Kubitschek - '50 years in 5' - provided an apt expression of the importance of accelerating time. It might be thought that this investigative approach was chosen because the modern order gradually imposed itself as something 'new' in the country, or because it represented the sociologists' ideals of modernity. The fact is that Brazilian sociology did not develop a universalist and abstract critique of the capitalist system and its desire to equalize and standardize everything, as Hannah Arendt observes, nor did it lament the loss of authority of the past, as Walter Benjamin did. Neither did it turn its attention to the destructive consequences of progress, whether moral or physical in kind. Naturally there were diverging approaches, something that I wrote about in my book Mudança provocada (Provoked change) (Villas Bôas, 2006a). However, the positions adopted in favour of progress, science and the future predominated.

In order to achieve their aims, the sociologists adopted a unique approach. Their studies foregrounded the differences in inclusion of men, women and children in the production process, revealing the deep inequalities existing in the country in a way never before seen in Brazil's cultural production. Misery and poverty were stamped in the figures of migrants from the northeasterners, migrants, labourers, peasants, former slaves, river dwellers, immigrants, fishing 
communities, the misfortunate of every kind. In exploring these social inequalities, they discovered that one of the factors preventing change was the weakness or complete absence of political authority in the face of the personal interests imposed by the wealthy and powerful. The sociologists realized that the 'past' had learnt how to negotiate with the country's projects for the future, enabling the coexistence and accommodation of very distinct temporalities. The research, whatever its orientation, revealed the profound connection between past and future. This discovery generated diverse explanations for a supposed pathological social and historical configuration, as well as condemnations of 'Brazilian' resistance to modernity. One of the most popular explanations at tributed Brazil's relative backwardness to its insertion in the modern during the colonial era. This original sin was transformed into a powerful topos that defined 'national destiny.' Not even the critiques of the devastating effects of progress, the end of the utopias and the failure of the philosophies of history that form part of the discursive repertoire in the present day have succeeded in undermining this emblematic explanation.

\section{THIRD PONDERATION: FUTURISM OR ORIGINAL COPIES?}

The disputes over the past and the future in the field of arts are intense. They appear in the written records of artists, historians and critics, for example, in the wide-ranging controversy over classifying art works, including modern and contemporary art. A shifting field, difficult to penetrate, the art world provides fertile ground for us to explore how much the valorisation of future and past fluctuate over time.

In the book On abstract art (I997), Briony Fer argues that abstract art, represented at the end of the I920s by Mondrian, Malevich and El Lissitzky, had been contested even before its recognition and consecration. The German critic Carl Einstein from the journal Documents, which united surrealists linked to George Bataille, was emphatic in asserting that artists making use of geometric forms were "moralists of the pure form, preaching the virtues of the square, drunk on mathematics" (cited in Fer, 2000: 2) and that "their works are no more than pure anxiety in the fact of the invisible and the sudden disappearance provoked by death" (cited in Fer, I997: 2-3). Seven decades later, Briony Fer took an opposite stance to the critics from Documents, arguing that the Russian suprematists and Dutch neoplasticists did nothing more than inscribe their fantasies of the modern in the straight lines and the ordered geometric forms that composed their works.

Some authors go further. Maarten Doorman (2003), who I cited earlier, stresses the influential role of the notion of progress in the avant-garde movements of the start of the twentieth-century. His analysis of the journal De Stijl, led by Mondrian and Van Doesburg, he emphasizes that spirituality and pure 
abstraction through the reduction of natural forms to geometric forms comprises one of the movement's ideals (see Figure I at page I 2 I). Attaining absolute harmony in an imperfect and chaotic world was one of the requirements set by Mondrian's utopian thought. In the set of eleven essays on "The new plastic in painting," published in the first volume of the journal in I9I7, Mondrian calls attention to the intellectualization and the automatization of the modern world:

The life of modern cultured man is gradually turning away from the natural: life is becoming more and more abstract. As the natural (external) becomes more and more 'automatic,' we see life's interest fixed more and more on the inward. The life of the truly modern man is neither toward the material [...] nor toward the predominantly emotional: rather, it takes the form of the autonomous life of the human spirit becoming conscious (Cited in Doorman, 2003: 88).

The demand for the spiritual and the universal was the starting point for artists who wanted to unite the dichotomies of universal versus individual, spiritual versus material, abstract versus concrete, objective versus subjective and rational versus emotional. Other oppositions - like those between positive and negative, male and female, vertical and horizontal, open forms and closed forms, multiplicity and unity, clear and vague - provided a synthesis of the new painting. Briony Fer recalls that Mondrian desired to achieve the illusion of a whole (all things) set out on a plane where the asymmetric grid and the coloured planes no longer seem to inhabit an embodied and three-dimensional world, but challenge a habitual way of searching for depth. Mondrian composed his planes in order for them to seem entirely logical, as though they were a totality, contained, disembodied. From this derived the metaphoric quality of his paintings (Fer, I997: 49-50).

Examining the descriptions of a geometric, constructivist or concrete form of abstract art more broadly, we can note see that the explanations for this new conception of art were varied and certainly distinct from one another, though they shared a point in common: the elimination of the past through the liberation of art from the object, description and mimesis. Max Bill - a Swiss artist based in Germany, whose ideas had a strong impact in Brazil when he travelled to the country and received an award at the First São Paulo Biennale - wrote poetically on the necessity of visual support to human thought, in particular mathematical thought, in the face of the unlimited: "from the moment when art intervenes, the clear becomes blurred, while abstract, invisible thought emerges as the concretely visible. Unknown spaces, almost unbelievable axioms, acquire a reality and one begins to walk through regions that once never existed: sensibility is expanded; spaces until recently unknown and unimaginable begin to be known and imagined" (Bill, I950: 5).

Soon after the end of the Second World War, concretism became established in Brazil under the leadership of the critic Mario Pedrosa, in Rio de Ja- 
neiro, and the critic and artist Waldemar Cordeiro (see Figure 2 at page I22) in São Paulo. Naturally there was considerable resistance to the new aesthetic, which abandoned the portraits of Brazil privileged by the modernist program of the I920s in favour of making visible the invisible, the point, the line, the plane. Otília Arantes provides an excellent summary of the political threat posed by the concrete movement. He calls attention to the resistance to abstractionism in Brazil, arguing that:

among us there is no conception of a cultural activity not in the service of the 'depiction' of the country, not simultaneously an instrument of knowledge and a consolidation of the 'image' of a country still very unsure of itself - to paint was to help discover [Brazil] and slowly build a nation diminished by the colonial complex [...]. While cubist primitivism and the expressionist deformation of a clear social inclination seemed to fit this program of plastic transposition of the country, it was imagined that this abstraction would force us to renounce all of this, that a tradition painstakingly achieved would be wiped out overnight [...] (Arantes, I996: II, 20).

As well as failing to match the national project, concrete art intensified the debate on the negative influence of rationalization in art to the extent that art critics frequently argued that geometric forms 'lost' their objective nature to become a vehicle of the imagination. I cannot enter into detail here on the disputes that traversed the Brazilian artistic field concerning the two competing projects of modernism. My goal, very different, is to show that the creation of new spaces that recreated themselves - through concretism - was associated with a modern conception of time and the rejection of a past that no longer served as a model for art.

A few decades after the recognition and consecration of concrete art, new concepts of art marked by the critique of the future and an obsession with memory gave rise to art objects whose baseline had shifted from the future to the past. The art historian Martha Buskirk (and I shall use the term contemporary art without any pretence of defining it) in her book The contingent object of contemporary art (2005) states that, by radically reworking the canons of the art of the past, contemporary art in fact enables a return to this past, selecting a fragment, an image, a citation that brings us this past back in renewed form, transfigured into a new context with a new meaning, remade, original.

In the book by Lilia Schwarcz and Adriana Varejão entitled Pérolas imperfeitas (20I4), the dialogues between the anthropologist/historian and the artist investigate the colonial past free of any normative vision. Dotted with the gems encountered by the artist over the course of her experiences, travels and readings, such as the Chinese stamps or the book by Hans Staden, Varejão's work conjures an atmosphere of colonial temporality, mixing and shaping the colonizer and colonized, dissolving centres and peripheries, diluting the dichotomies so often taught, questioning the memory harshly punished by the 
crystallization of negative views of the Brazilian past. Celacanto provoca maremoto (see Figure 3 at page I23), exhibited in Inhotim, provides a paradigmatic example of a new expressive form that revers the past, recreating it. The use of a multiplicity of media and sources (painting, documentation, ceramic tiles, objects, citations) does not mean, as Martha Buskirk observes, that the associations with images, memories and objects are effective. They simply retain traces of past histories in a creative process that composes an aesthetic expression through which new connections are established (Buskirk, 2005: 65). More than a mere transposition, these connections are a mark of the artist's choice, her authorship.

As I said at the start of this text, it has not been my objective to contribute to the critique of modernity, much less take its side, but rather to rethink the discursive polarities generated by modernity (and its relation with the teleologies of the everyday). Along these lines, returning to the ponderations made above, I observe that the critical and non-critical discourses of modernity function as an amplifier in the flow of time. It might be wondered whether they are just two sides of the same entity, but I don't think so: the difference can be perceived in the relation between discourse, narrative or semantics and social structures. To what extent, for example, have the discourses in favour of recent technological advances worked to legitimize the intensification of social relations at a global scale, linking distant localities and shaping local events through events that occur many miles away? How to compare their impact with the Weberian critique of the lack of meaning to life provoked by the infinitude of progress? Or with the critiques of contemporary artistic poetics aimed at a radical revision of the prerogative of the European colonizer to narrate the history of colonization? The variability in the transformative force of critique is itself a complex problem. But although this critique emphasizes this difference in the discourses polarized under modernity, presuming that the discourse legitimizing the social order contributes to the maintenance of progress more than the poetics that resist it, it may well be that the core of the social order that transpires in the quotidian world of social relations and the teleologies of the everyday is entirely unaffected by either pole of the semantic debate on modernity. Indeed it would appear that the modern social order is immune to any critique. In the regularity of its everyday events it imposes itself as all-powerful and impenetrable. 


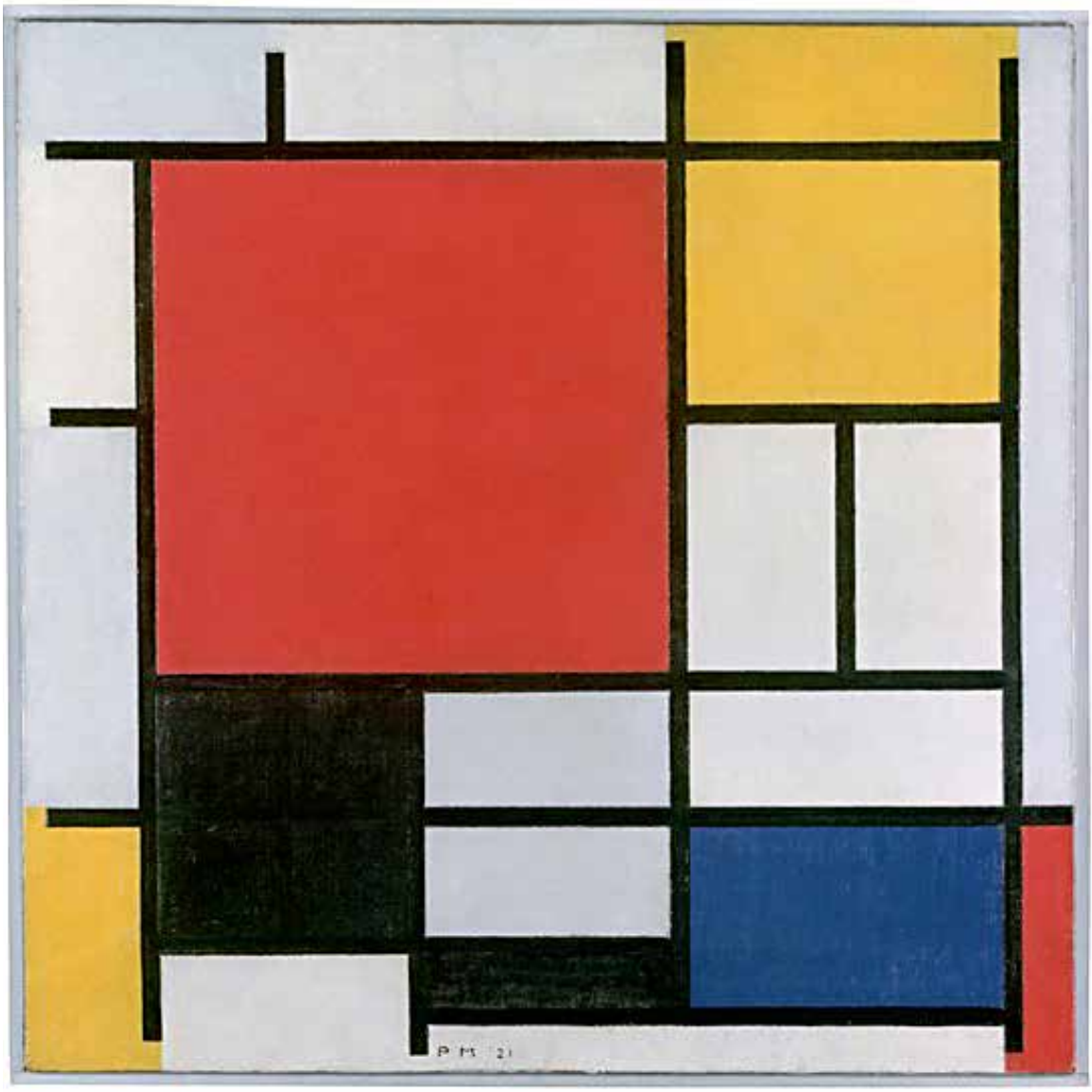

I

I

Piet Mondrian (I926)

Composition in Red,

Yellow, Blue and Black.

Oil on canvas, $59.5 \times 59.5 \mathrm{~cm}$

Gemeentemuseum, Den Haag 


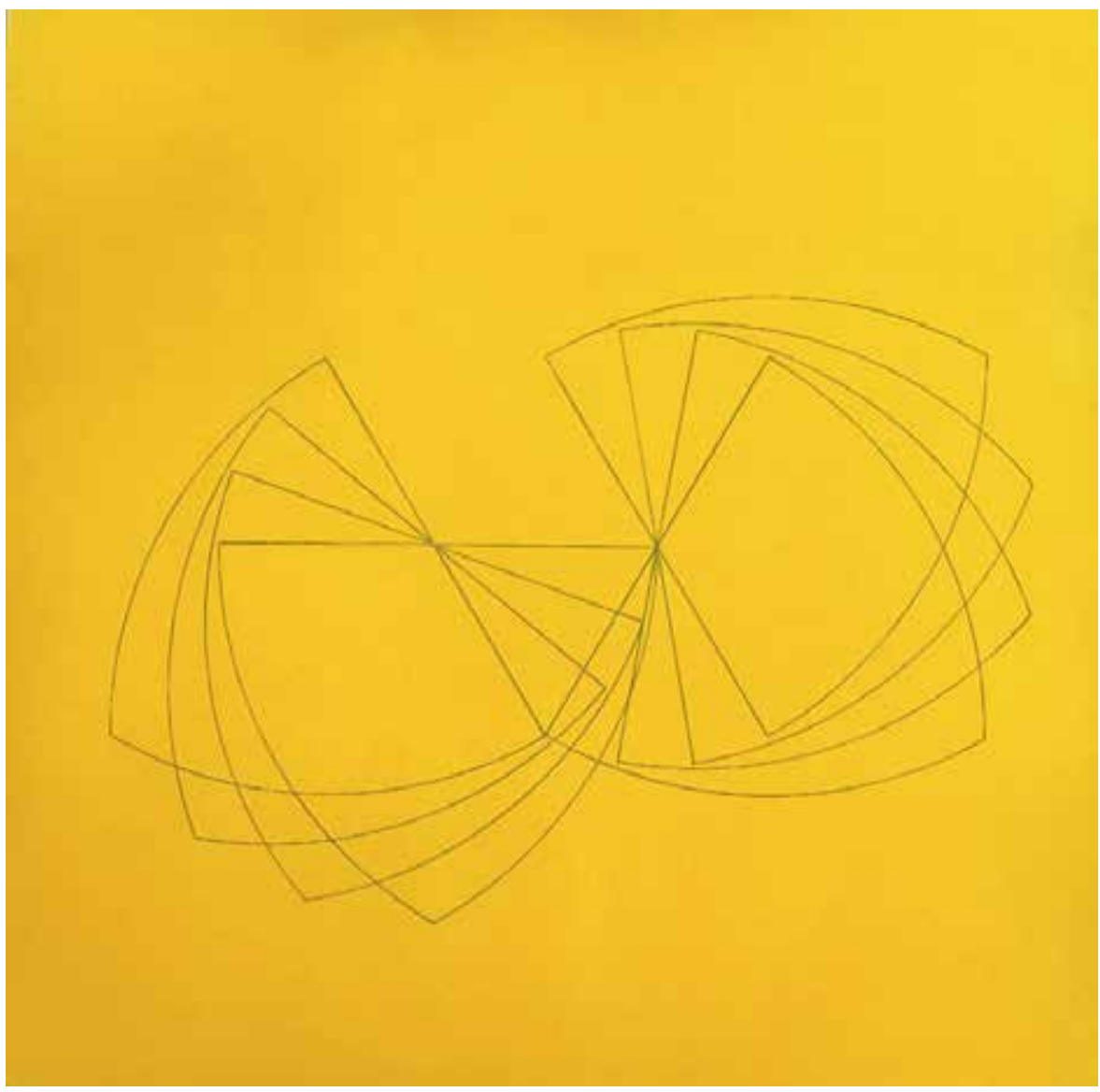




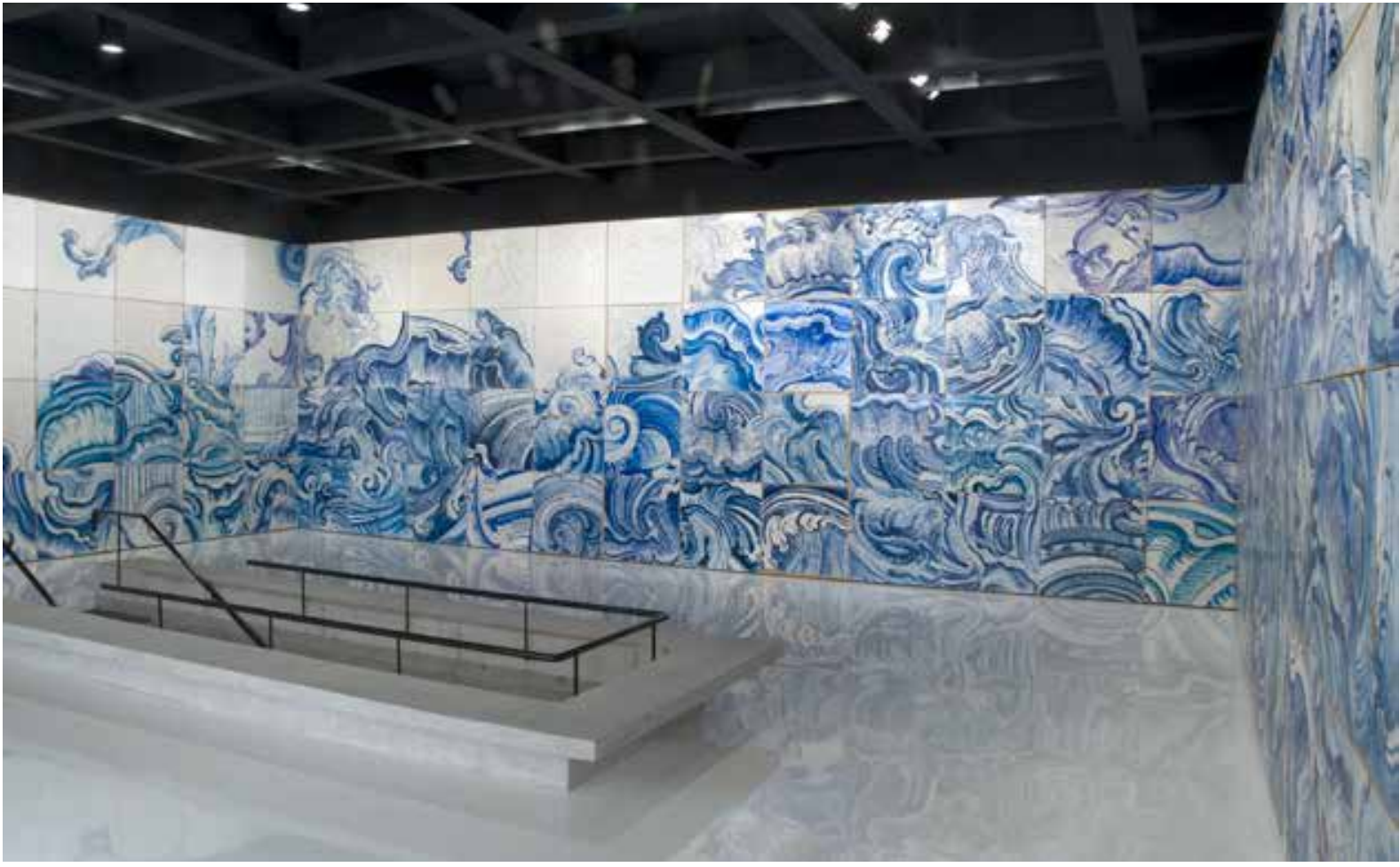

3

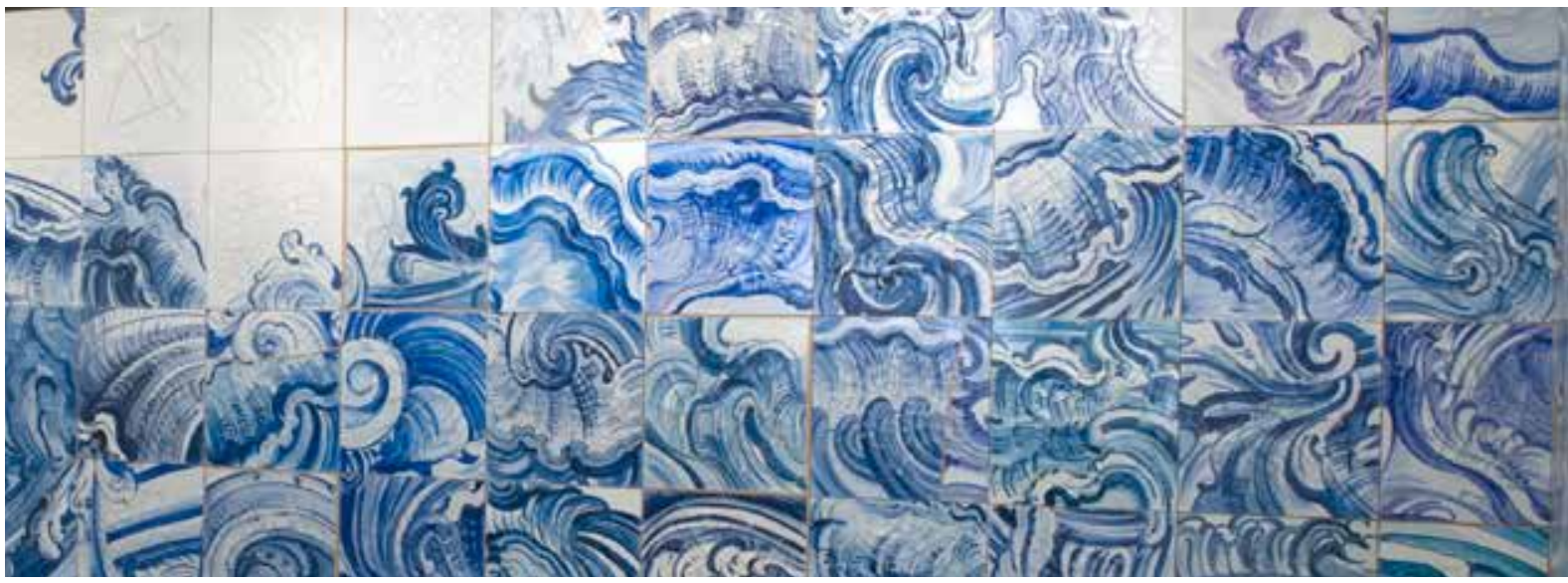

3

Adriana Varejão

Celacanto provoca maremoto

(2004-2008)

Oil and plaster on canvas.

I IO $\mathrm{x}$ IIocm each piece

I84 pieces

Inhotim

Photo Vicente de Mello 


\section{NOTE}

I Change, time and sociology was the theme of a talk presented on the occasion oåf my promotion to the post of full professor of the Department of Sociology at UFRJ, on May $22^{\text {nd }} 2015$. I thank my colleagues, the editors of Sociologia \& Antropologia, for the opportunity to publish it.

Glaucia Villas Bôas is a professor in the Department of Sociology at Federal University of Rio de Janeiro. Her teaching and researches concern sociology of culture, focusing on sociological theory, social thought as well as modern and contemporary art. She published Mudança provocada (2006), A recepção da sociologia alemã no Brasil (2006) and A vocação das Ciências Sociais no Brasil I945-I966 (2008) in addition to papers regarding her research interests. 


\section{BIBLIOGRAPHY}

Arantes, Otília. (I996). Pedrosa, um capítulo brasileiro da teoria da abstração. In: Arantes, Otília (org.). Formas e percepção estética: textos escolhidos II/Mario Pedrosa. São Paulo: Edusp.

Bill, Max. (I950). El pensamiento matemático en el arte de nuestro tiempo. Ver y estimar: cuadernos de crítica artística, I7, Buenos Aires, p. I-7.

Buskirk, Martha. (2005). The contingent object of contemporary art. Cambridge, MA: The MIT Press.

Doorman, Maarten. (2003). Art in progress. A philosophical response to the end of the avant-garde. Amsterdam: Amsterdam University Press.

Durkheim, Émile. (1982). O suicídio. Rio de Janeiro: Zahar.

Fer, Briony. (2000). On abstract art. New Haven/London: Yale University Press.

Koselleck, Reinhardt. (2006). Passado futuro: contribuição à semântica dos tempos históricos. Rio de Janeiro: Contraponto/Ed. PUC.

Schwarcz, Lilia \& Varejão, Adriana. (20I4). Pérola imperfeita: a história e as histórias na obra de Adriana Varejão. Rio de Janeiro: Cobogó.

Tolstoi, Leão. (I993). A morte de Ivan Ilitch. Obra Completa. Lisboa: Nova Aguilar (vol. III).

Villas Bôas, Glaucia. (2006a). Mudança provocada. Passado e futuro no pensamento sociológico brasileiro. Rio de Janeiro: Ed. FGV.

Villas Bôas, Glaucia. (2006b). Ascese e prazer: Weber versus Sombart. In: A recepção da sociologia alemã no Brasil. Rio de Janeiro: Topbooks, p. 29-57.

Weber, Max. (I999). Economia e sociedade: fundamentos da sociologia compreensiva, Brasília: Ed. UnB (vol. 2).

Weber, Max. (1995). Wissenschaft als Beruf. Stuttgart: Philip Reclam jun. 


\section{MUDANÇA, TEMPO E SOCIOLOGIA}

Resumo

$\mathrm{O}$ artigo retoma a polaridade dos discursos contra e a favor da modernidade, argumentando que, ao limitar-se à esfera própria da cultura, tais discursos negligenciam outras ordens sociais igualmente constitutivas da sociedade moderna. Por este motivo, tanto a crítica quando a apologia criam distorções entre o entendimento da modernidade e as estruturas sociais. Depois de questionar as concepções críticas da sociologia clássica e a adesão da sociologia brasileira à modernidade, a autora questiona o privilégio atribuído ora ao tempo futuro, ora ao tempo passado nos estudos sobre a arte moderna e contemporânea.

\section{CHANGE, TIME AND SOCIOLOGY}

Abstract

This article readdresses the polarity of discourses against and in favor of modernity. It argues that by limiting themselves to the sphere peculiar to culture, these discourses neglect other social spheres that are equally constitutive of modern society. Both critics and apologists of modernity eventually create a distortion between understandings of modernity and social structures. After reassessing critical assumptions of classical sociology and the affirmation of modernity within Brazilian sociology, the author explores the shifting privilege of future and past times within studies of modern and contemporary art.
Palavras-chave

Modernidade;

Crítica e apologia;

Tempo;

Sociologia;

Arte.

Keywords

Modernity;

Critic and apology;

Time;

Sociology;

Art. 